\title{
Morphological and Molecular Analysis Using RAPD in Biofield Treated Sponge and Bitter Gourd
}

\author{
Mahendra Kumar Trivedi ${ }^{1}$, Alice Branton ${ }^{1}$, Dahryn Trivedi ${ }^{1}$, Gopal Nayak ${ }^{1}$, Mayank Gangwar ${ }^{2}$, \\ Snehasis Jana ${ }^{2, *}$ \\ ${ }^{1}$ Trivedi Global Inc., Henderson, USA \\ ${ }^{2}$ Trivedi Science Research Laboratory Pvt. Ltd., Bhopal, Madhya Pradesh, India
}

Email address:

publication@trivedisrl.com (S. Jana)

\section{To cite this article:}

Mahendra Kumar Trivedi, Alice Branton, Dahryn Trivedi, Gopal Nayak, Mayank Gangwar, Snehasis Jana. Morphological and Molecular Analysis Using RAPD in Biofield Treated Sponge and Bitter Gourd. American Journal of Agriculture and Forestry.

Vol. 3, No. 6, 2015, pp. 264-270. doi: 10.11648/j.ajaf.20150306.14

\begin{abstract}
Plants are known to have sense and can respond to touch, electric and magnetic field. The present study was designed on the sponge gourd (Luffa cylindrica) and bitter gourd (Momordica charantia) seeds with respect to biofield energy treatment. The seeds of each crop were divided into two groups, one was kept control, while the other group was subjected to Mr. Trivedi' biofield energy treatment. The variabilities in growth contributing parameters were studied and compared with their control. To study the genetic variability after biofield energy treatment, both the seeds were analyzed for DNA fingerprinting using RAPD method. After germination, the plants of sponge gourd were reported to have uniform colored leaves and strong stem. The leaves and fruits of sponge gourd showed no infection, with anti-gravity properties during early stage of fruiting as compared with the control group. Similarly, treated bitter gourd showed uniform color of leaves, strong stem, with disease free fruits in biofield treated seeds as compared with the control. The true polymorphism (\%) observed between control and treated samples of sponge and bottle gourd seed sample was an average value of $7.8 \%$ and $66 \%$ respectively. In conclusion, Mr. Trivedi's biofield energy treatment has the ability to alter the plant growth rate that may by interacting with plant genome, which resulted in high yield of crops.
\end{abstract}

Keywords: Luffa cylindrica, Momordica charantia, Biofield energy, Growth Attributes, DNA Fingerprinting, Polymorphism

\section{Introduction}

The gourd is generally used to describe the crop plants in the family Cucurbitaceae. The term gourd refers to around 825 species derived from tropical and subtropical regions, out of which approximately 26 species are cultivated as vegetables [1]. One of the important and common fruit of cucurbitaceous crop is sponge gourd (Luffa cylindrica), originating in India and southern Asia. Besides its vegetative importance, members of this group were grown for ornament purposes. Sponge gourd fruits and their seeds are used in the traditional medicine as stomachic, antipyretic, anti-helmintic, and other related medicinal importance [2].

Another important and commonly available plant is bitter gourd (Momordica charantia) of family Cucurbitaceae, valued for its nutritional and several medicinal properties. It is also known as bitter melon, karela, or balsam pear, and is the most popular plant for diabetes management [3]. This crop also originates from India, and diversity has been reported in China but widely cultivated and used in India, Malaysia, Africa, and South America [4, 5]. Its fruit has been used from centuries in ancient traditional medicinal purpose due to its antimicrobial, antidiabetic, antiviral and antioxidant activities [6,7]. Based on the historical reports [4] and RAPD molecular analysis, maximum diversity was reported in eastern India [8].

Identification of genetic diversity based on phenotypic character is very limiting, as an environmental factors and plant developmental stage will affect the morphological characters of plant. However, DNA polymorphism based upon molecular markers are independent of environmental conditions, which shows a high level of polymorphism. Molecular markers shows variation in the genome which may be expressed or not, while morphological markers reflects 
variation in expressed regions [9]. Randomly amplified polymorphic DNAs (RAPD) analysis shows maximum genetic relatedness among plant genome due to their simplicity, speed and low-cost [10].

To improve the crop yield, growth characters, and protect the crop from infections, different methods have been adopted such as genetic engineering, plant growth hormones, tissue culture, altered environmental parameters, use of fertilizers, pesticides, and many more [11]. Apart from these traditional approaches, recent reports suggest increased germination, yield, growth and its related parameters with the use of electric and magnetic field on seeds before germination [12-14]. Some alternative techniques such as exposure of electromagnetic field on seeds have shown good results with improved yield, as biofield energy is a form of low intensity electromagnetic field [15]. Authors have intended to study the impact of biofield energy treatment on the seeds of sponge and bitter gourd. Energy treatment as an alternative integrative medicine approach has been recently introduced to promote human wellness by National Center for Complementary and Alternative Medicine (NCCAM) [15]. Biofield is the name given to the electromagnetic field that permeates and surrounds living organisms. It is the scientifically preferred term for the biologically produced electromagnetic and subtle energy field that provides regulatory and communication functions within the organism. The objects always receive the energy and responding to the useful way that is called biofield energy treatment. Mr. Trivedi's unique biofield treatment is known as The Trivedi Effect ${ }^{\circledR}$. Mr. Trivedi is having the unique biofield energy, which has been reported in several research areas [16-19].

Due to the importance of sponge and bitter gourd as vegetable and medicinal importance, and previous results of biofield treatment, the present study was designed to evaluate the effect of biofield energy treatment on sponge and bitter gourd. Genetic variability parameters of both the crops were studied using RAPD (DNA fingerprinting).

\section{Materials and Methods}

Sponge gourd (Luffa aegyptiaca) and bitter gourd (Momordica charantia) were selected for present study due to their high vegetative importance. Nirmal 28 variety of sponge gourd, and Nirmal 167 (Savitri) of bitter gourd were procured from Nirmal Seeds, Jalgoan, Maharashtra, India. Each variety of the seeds was divided into two parts, one part was considered as control, while other part was coded as treated and subjected to Mr. Trivedi's biofield energy treatment. Seeds from each group were cultivated in Shahapur agricultural land in Maharashtra for analysis. However, the control plants were given standard cultivation parameters such as proper irrigation, fertilizers, pesticides and fungicides; while the treated plants were given only irrigation, without any supportive measure. DNA fingerprinting of both the plants were performed using random amplified polymorphic DNA (RAPD) techniques using Ultrapure Genomic DNA Prep Kit; Cat KT 83 (Bangalore Genei, India) to study the genetic relationship before and after treatment.

\subsection{Biofield Treatment Strategy}

The treated groups of seeds were subjected to Mr. Trivedi's biofield energy treatment under standard laboratory conditions. Mr. Trivedi provided the unique biofield treatment through his energy transmission process to the treated group of both the seeds without any touch. The treated samples were assessed for the growth germination of seedlings, leaves, length of plant, and rate of infections. Variability in different growth contributing parameters and genetic relatedness using RAPD of control and treated crops were compared [16].

\subsection{Analysis of Growth and Related Parameters of Crops}

Control and treated seeds of sponge gourd and bitter gourd were cultivated under similar conditions. Vegetative growth of the crops with respect to plant height, canopy, the shape of leaves, flowering conditions, infection rate, etc. were analyzed and compared with respect to the control group [20].

\subsection{DNA Fingerprinting in Sponge and Bitter Gourd}

\subsubsection{Isolation of Plant Genomic DNA Using CTAB Method}

Leaves disc of each plants was harvested after germination when the plants reached the appropriate stage. Genomic DNA from both plant leaves was isolated according to the standard cetyl-trimethyl-ammonium bromide (CTAB) method [21]. Approximately $200 \mathrm{mg}$ of plant tissues were grinded to a fine paste in approximately $500 \mu \mathrm{L}$ of CTAB buffer. The mixture (CTAB/plant extract) was transferred to a microcentrifuge tube, and incubated for about $15 \mathrm{~min}$ at $55^{\circ} \mathrm{C}$ in a recirculating water bath. After incubation, the mixture was centrifuged at $12000 \mathrm{~g}$ for $5 \mathrm{~min}$ and the supernatant was transferred to a clean microcentrifuge tube. After mixing with chloroform and iso-amyl alcohol followed by centrifugation the aqueous layers were isolated which contain the DNA. Then, ammonium acetate followed by chilled absolute ethanol were added, to precipitate the DNA content and stored at $-20^{\circ} \mathrm{C}$. The RNase treatment was provided to remove any RNA material followed by washing with DNA free sterile solution. The quantity of genomic DNA was measured at $260 \mathrm{~nm}$ using spectrophotometer [22].

\subsubsection{Random Amplified Polymorphic DNA (RAPD) Analysis}

DNA concentration was considered about $25 \mathrm{ng} / \mu \mathrm{L}$ using distilled deionized water for polymerase chain reaction (PCR) experiment. The RAPD analysis was performed on the each treated seeds using RAPD primers, which were label as RPL 2A, RPL 7A, RPL 12A, RPL 14A, RPL 18A, and RPL 23A for sponge gourd and RPL 4A, RPL 5A, RPL 6A, RPL $13 \mathrm{~A}$, and RPL 19A for bitter gourd. The PCR mixture including $2.5 \mu \mathrm{L}$ each of buffer, $4.0 \mathrm{mM}$ each of dNTP, 2.5 
$\mu \mathrm{M}$ each of primer, 5.0 $\mu \mathrm{L}$ (approximately $20 \mathrm{ng}$ ) of each genomic DNA, $2 \mathrm{U}$ each of Thermus aquaticus (Taq) polymerase, $1.5 \mu \mathrm{L}$ of $\mathrm{MgCl}_{2}$ and $9.5 \mu \mathrm{L}$ of water in a total of $25 \mu \mathrm{L}$ with the following PCR amplification protocol. For sponge gourd, initial denaturation at $94^{\circ} \mathrm{C}$ for $5 \mathrm{~min}$, followed by 40 cycles of annealing at $94^{\circ} \mathrm{C}$ for $1 \mathrm{~min}$, annealing at $36^{\circ} \mathrm{C}$ for $1 \mathrm{~min}$, and extension at $72^{\circ} \mathrm{C}$ for $2 \mathrm{~min}$, while final extension was carried out at $72^{\circ} \mathrm{C}$ for $10 \mathrm{~min}$. For bitter gourd, initial denaturation at $94^{\circ} \mathrm{C}$ for $7 \mathrm{~min}$, followed by 8 cycles of annealing at $94^{\circ} \mathrm{C}$ for $45 \mathrm{sec}$, annealing at $35^{\circ} \mathrm{C}$ for $1 \mathrm{~min}$, and extension at $72^{\circ} \mathrm{C}$ for $1.5 \mathrm{~min}$. Further, 35 cycles was carried out at $94^{\circ} \mathrm{C}$ for $45 \mathrm{sec}, 40^{\circ} \mathrm{C}$ for $60 \mathrm{sec}$, and $72^{\circ} \mathrm{C}$ for $60 \mathrm{sec}$. While, final extension was carried out at $72^{\circ} \mathrm{C}$ for $7 \mathrm{~min}$. Amplified PCR products $(12 \mu \mathrm{L}$ of each) from control and treated samples were loaded on to $1.5 \%$ agarose gel and resolved by electrophoresis at 75 volts. Each fragment was estimated using 100 bp ladder (Genei ${ }^{\mathrm{TM}}$; Cat \# RMBD19S). The gel was subsequently stained with ethidium bromide and viewed under UV-light [23]. Photographs were documented subsequently. The following formula was used for calculation of the percentage of polymorphism.

$$
\text { Percent polymorphism }=\mathrm{A} / \mathrm{B} \times 100
$$

Where, $\mathrm{A}=$ number of polymorphic bands in treated plant; and $\mathrm{B}=$ number of polymorphic bands in the control plant.

\section{Results and Discussion}

\subsection{Effect of Biofield Treatment on Different Growth Contributing Parameters of Sponge Gourd}

The untreated seeds of sponge gourd after germination showed that leaves were thicker than the treated group and the color was not uniform. This might be the symbol of initiation of infections resulted in poor yield of the crop. A large number of leaves in control plants had a rough and bubble-like surface due to the infections. The stem was tender and could be easily bent in control crops, which resulted in loss of crop yield. The plants showed high incidence of disease with dots on the leaves, and they were attacked by insects.

The biofield treated seeds of sponge gourd plants showed that the leaves were thinner than the control group and the color was uniform. The leaves had very smooth surfaces with no disease or insect attack. The fruits showed anti-gravity properties during early stage of fruiting. Normally, the fruit gravitates downwards due to weakness in the stem of the fruit, but the biofield treated plant's stem was so strong that the fruit was held up and pointed towards the sun.

Biofield energy treated fruits of sponge gourd was reported to be healthy with respect to quality and shape of fruit. Sponge fruit inheritance and its quality traits has been previously reported [24, 25]. Reports suggest that quantitative traits of fruit shape can be controlled by its gene expression and regulation during the maturation period of plant. This qualitative trait could control be controlled by different genetic mechanisms at different developmental stages. However, correlations has been well reported at different developmental stages with various genetic effects [26]. So, it can be assumed that biofield energy treatment might alter the genetic mechanism of sponge gourd, which is responsible for the better growth of sponge plant and fruits.
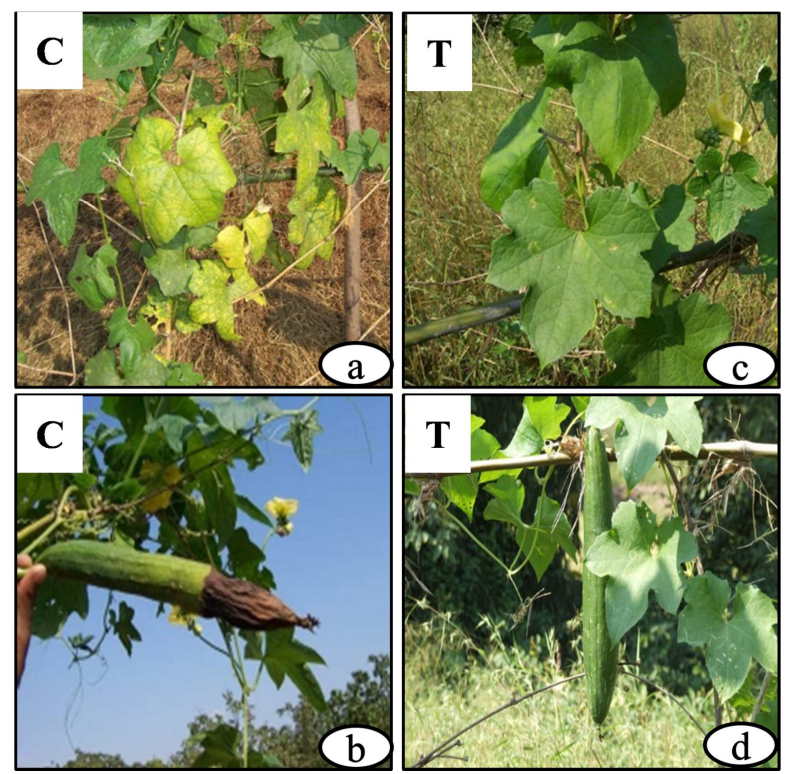

Figure 1. The Trivedi Effect ${ }^{\circledR}$ on sponge gourd (a) leaf of control plants were reported as pale yellow depicts the symptoms of infection, (b) control sponge fruit showed infection and unhealthy fruits, (c) biofield treated leaves of sponge gourd were free from any kind of disease or pest attack, (d) biofield treated seeds showed healthy plant growth and fruits free from any infections result in high yield. C: Control; T: Treated.

\subsection{Effect of Biofield Treatment on Different Growth Contributing Parameters of Bitter Gourd}
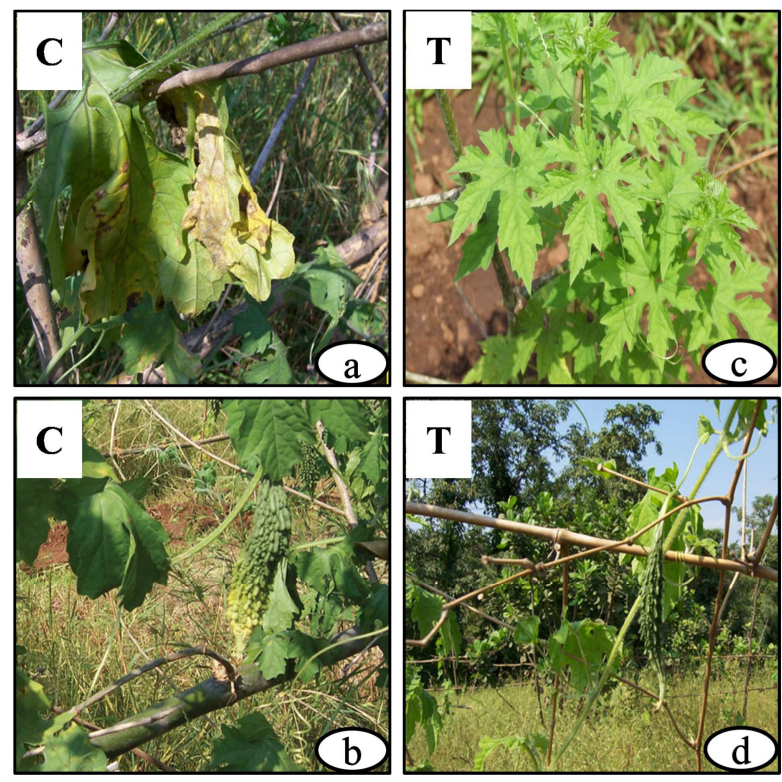

Figure 2. Effect of biofield energy treatment on bitter gourd (a) control leaves of bitter gourd reported with irregular yellowish patches, infections and circular patches or spots appear, (b) control seeds of bitter gourd plant showed fruits with curved shape fruit do not develop fully and remain small, (c) biofield treated group showed healthy leaves and all are free from pest attack, (d) biofield treated group showed that bitter gourd fruits are long, fresh, and free from infection. C: Control; T: Treated. 
The growth in case of control bitter gourd was good, but the stem was very tender. Many leaves were diseased with yellow spots, and there were signs of insect attack on both the leaves and fruits of bitter gourd in the control group. The color of the leaves were yellowish-green and it was not uniform throughout the control group in bitter gourd.

The growth in biofield treated bitter gourd plants was also comparable, the leaves were of uniform color and the stem of bitter gourd plant was quite strong. The plants were absolutely disease-free and even the fruits were not attacked by any kind of insects. Therefore, it can be concluded that biofield treated bitter gourd might yield more healthy fruits than compared with the control. According to the recent report of Mahajan et al, the seeds of bitter gourd respond differently, when exposed to varying level of electric and magnetic field. They showed that seeds become polarized in the presence of altered field, while after removal of electromagnetic field seeds retain some level of polarization, known as remnant polarization. During germination, these seeds when come in contact with the water dipoles, an interaction between the water dipoles and seed dipoles taken place. These dipole interaction, results in the level of water uptake by the seeds, which improves the germination time and rate [13]. It can be assumed that $\mathrm{Mr}$. Trivedi's biofield energy treatment might affect the polarization of bitter gourds seeds in treated group, and results in better dipole interaction of seeds and water. Hence, biofield treated seeds were reported with high germination rate, better growth, and less infections as compared with the control.

According to a latest report, the plants respond to the different environmental conditions such as geomagnetism, gravity response, electric signal, touch effect, wavelength of light, and many more. These all factors contributes and effect the final growth of plants at different stages. A report suggest that magnetic field exposure will increase the growth rate and have effect on plant roots and shoots [27]. Another report suggests that geomagnetic field has effect on activated state of cryptochromes, which resulted in modification of function and alters the growth yield [28]. Magnetic field exposure has been reported with increased level of photosynthesis, stomatal conductance and chlorophyll content in corn plants compared to the control under similar irrigated and mild stress condition [29]. It can be hypothesized that on exposure of biofield energy treatment on sponge and bitter gourd seeds, energy provided might change their paramagnetic behaviors, and orient themselves in the direction of positive energy, which leads to improved plant growth. It can be suggested that improved overall growth of plants and fruits of sponge and biter gourd could be due to improved level of photosynthesis and chlorophyll content.

Biofield energy is a type of energy medicine, under the category of complementary and alternative medicine (CAM), which basically involves low-level energy field interactions, and includes energy therapy, bio-electromagnetic therapy, etc. The improved growth contributing parameters of sponge and bitter gourd after biofield treatment may be the new alternative approach for better growth of pants and fruits.

\subsection{RAPD Analysis of Biofield Treated Sponge and Bitter Gourd}

Genetic analysis using RAPD molecular markers has been widely accepted technique in agriculture for improvement in vegetable crops [30]. By designing different RAPD markers related to samples, important information for genetic diversity can be evaluated for different plant species samples. Besides genetic diversity, population genetics study, pedigree analysis and taxonomic discrimination can also be correlated [23]. However, it has been proposed to be a powerful tool to evaluate differences between inter- and intra-population organisms including plants [31]. Biofield energy treatment might be a new approach in agriculture science, which can alter the genetic variability of the plant, improved yield of crops, growth, and high immunity along with change in chlorophyll content. Biofield treatment was reported with high genetic variability among species using RAPD fingerprinting [16]. However, the effect was also reported in case of biofield treated ginseng, blueberry [32], and lettuce, tomato [33] with an improved overall agronomical characteristics.

Biofield energy treated sponge and bitter gourd were analyzed and compared with their respective control for their epidemiological relatedness and genetic characteristics. Genetic similarity or mutations between the biofield treated and the control group was analyzed using RAPD. Both the samples required a short nucleotide random primers, which were unrelated to known DNA sequences of the target genome. DNA polymorphism can be efficiently detected using PCR primers and identify inter-strain variations among plant species after the biofield energy treatment. The degree of relatedness and genetic mapping can be correlated between similar or different treated samples.

Table 1. DNA polymorphism of sponge gourd analyzed after biofield treatment using random amplified polymorphic DNA (RAPD) analysis.

\begin{tabular}{|c|c|c|c|c|c|}
\hline \multirow{2}{*}{ S. No. } & \multirow{2}{*}{ Primer } & \multirow{2}{*}{$\begin{array}{l}\text { Band } \\
\text { Scored }\end{array}$} & \multirow{2}{*}{$\begin{array}{l}\text { Common bands in } \\
\text { control and } \\
\text { treated }\end{array}$} & \multicolumn{2}{|c|}{ Unique band } \\
\hline & & & & Control & Treated \\
\hline 1. & RPL 2A & 17 & 17 & 1 & - \\
\hline 2. & RPL 7A & 15 & 15 & 1 & - \\
\hline 3. & RPL 12A & 11 & 11 & - & - \\
\hline 4. & RPL 14A & 16 & 16 & - & - \\
\hline 5. & RPL 18A & 13 & 13 & - & - \\
\hline 6. & RPL 23A & 12 & 12 & - & - \\
\hline
\end{tabular}

Random amplified polymorphic-DNA fragment patterns of control and treated sponge gourd samples were generated using six RAPD primers, and 100 base pair DNA ladder. The results of DNA polymorphism in control and treated samples are presented in Figure 3. The DNA profiles of treated group were compared with their respective control. The polymorphic bands observed using different primers in control and treated samples were marked by arrows. The results of RAPD patterns in biofield treated sponge gourd sample showed some unique, common and dissimilar bands 
as compared with the control. DNA polymorphism analyzed by RAPD analysis, showed different banding pattern in terms of total number of bands, and common, and unique bands, which are summarized in Table 1. The percentage of polymorphism between samples were varied in all the primers, and were ranged from 6.6 to $9 \%$ between control and treated samples. However, level of polymorphism was only detected using the primer RPL $2 \mathrm{~A}$ and RPL 7A was found to be 6.6 and $9 \%$, respectively, while rest of the used primers did not show any level of polymorphism.

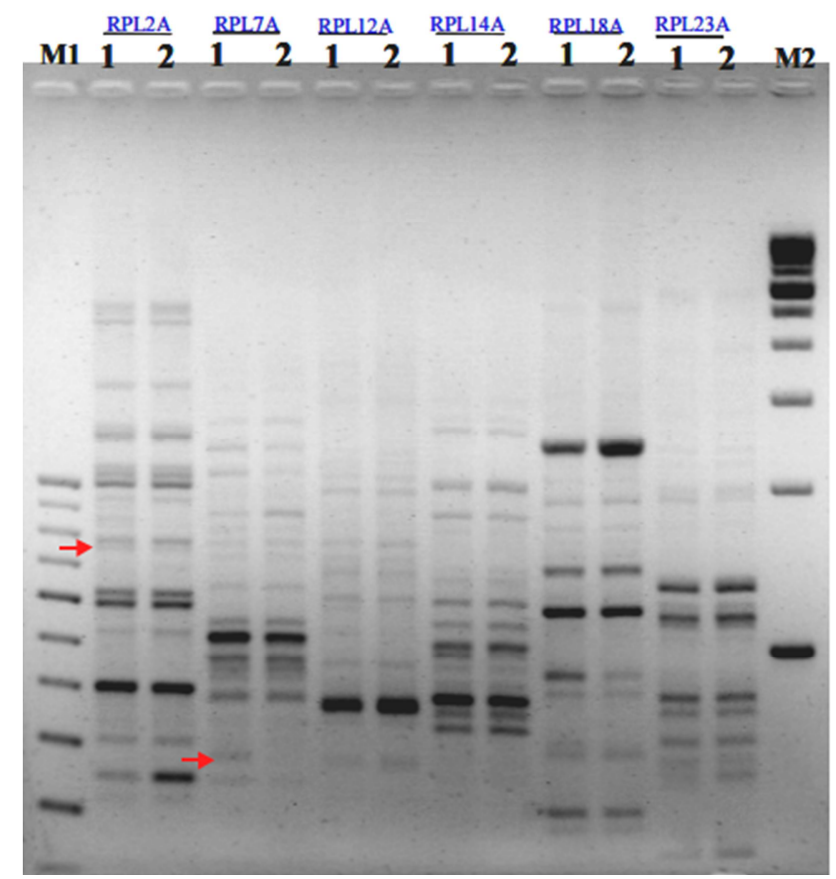

Figure 3. Random amplified polymorphic-DNA fragment patterns of biofield treated sponge gourd generated using 6 RAPD primers, RPL $2 A, R P L 7 A$, RPL 12A, RPL 14A, RPL 18A and RPL 23A. M: 100 bp DNA Ladder; Lane 1: Control; Lane 2: Treated.

Table 2. DNA polymorphism of bitter gourd analyzed after biofield treatment using random amplified polymorphic DNA (RAPD) analysis.

\begin{tabular}{|c|c|c|c|c|c|}
\hline \multirow[b]{2}{*}{ S. No. } & \multirow[b]{2}{*}{ Primer } & \multirow{2}{*}{$\begin{array}{l}\text { Band } \\
\text { Scored }\end{array}$} & \multirow{2}{*}{$\begin{array}{l}\text { Common bands } \\
\text { in control and } \\
\text { treated }\end{array}$} & \multicolumn{2}{|c|}{ Unique band } \\
\hline & & & & Control & Treated \\
\hline 1. & RPL 4A & 12 & 2 & 7 & 1 \\
\hline 2. & RPL 5A & 12 & 1 & 2 & 1 \\
\hline 3. & RPL 6A & 10 & 2 & 4 & 5 \\
\hline 4. & RPL 13A & 8 & - & 4 & 1 \\
\hline 5. & RPL 19A & 9 & 1 & 4 & 6 \\
\hline
\end{tabular}

Similarly, a very high level for polymorphism was detected in biofield treated bitter gourd samples using five primers. Different banding pattern was observed using RAPD DNA polymorphism in terms of total number of bands, and common, and unique bands, which are summarized in Table 2. The polymorphic bands observed using different primers in control and treated samples of bitter gourd were marked by arrows in Figure 4. The level of polymorphism percentage in bitter gourd samples were varied in all the primers, and were ranged from 8 to $100 \%$ between control and treated samples. However, level of polymorphism was detected as $8 \%, 42 \%$,
$100 \%, 83 \%$, and $100 \%$ using the primer RPL 4A, RPL 5A, RPL 6A, RPL 13A, and RPL 19A respectively. Highest level of polymorphism was detected using two primers namely RPL 6A, and RPL 19A i.e. 100\%, while minimum level of polymorphism ( $8 \%$ ) was detected using primer RPL 4A.

\section{RPLAA RPL5A RPL6A RPL13A RPL19A}

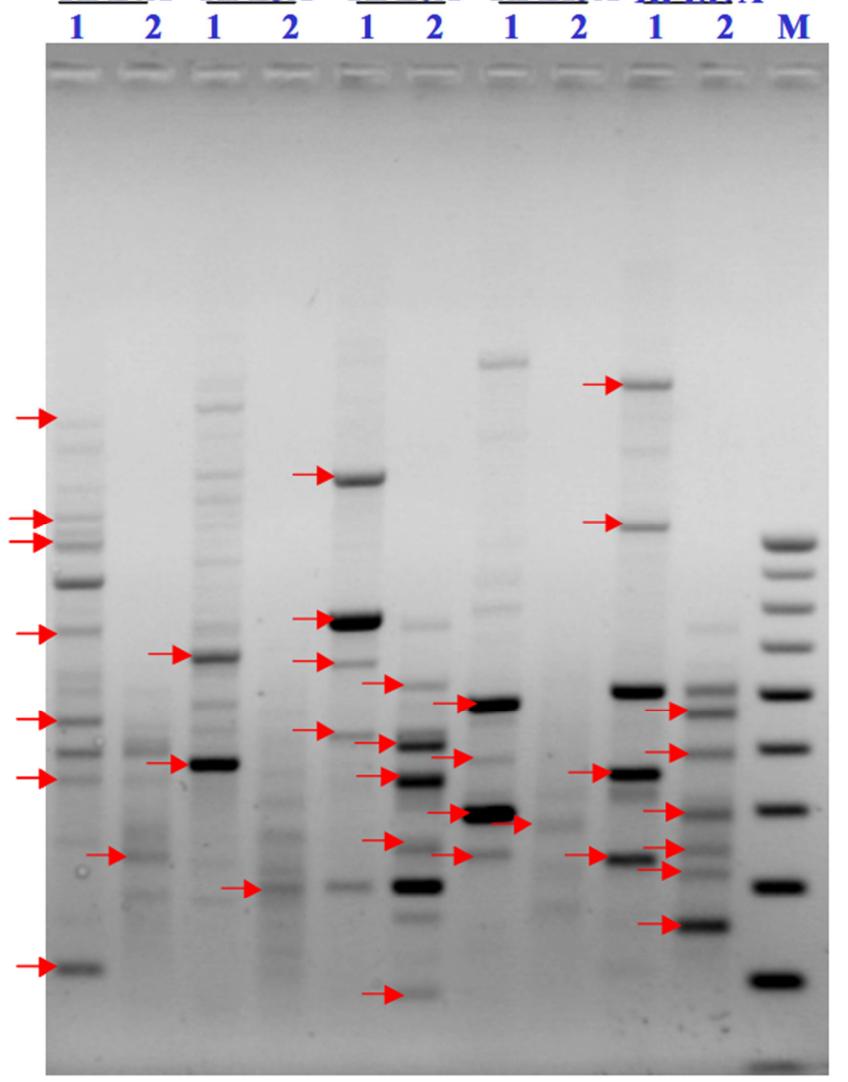

Figure 4. Random amplified polymorphic-DNA fragment patterns of biofield treated bitter gourd generated using 5 RAPD primers, RPL 4A, RPL 5A, RPL 6A, RPL 13A and RPL 19A. M: 100 bp DNA Ladder; Lane 1: Control; Lane 2: Treated.

RAPD analysis using different primers explains the relevant degree of genetic diversity among the tested samples. Overall, RAPD showed that polymorphism was detected between control and treated samples. The percentage of true polymorphism observed between control and treated samples of sponge and bottle gourd seed sample was an average value of $7.8 \%$ and $66 \%$, respectively.

However, RAPD is a tool which will detect the potential of polymorphism throughout the entire tested genome. After biofield treatment, higher number of polymorphic bands in bitter gourd sample than sponge gourd sample indicated that the genotypes selected in bitter gourd possess a higher degree of polymorphism compared with sponge gourd. Molecular analyses and genetic diversity of bitter gourd have been well defined [34]. After biofield treatment, level of polymorphism was reported in both the crops, which suggested that Mr. Trivedi's biofield energy treatment might have the capability to alter the genetic character of plants, which might be useful in terms of productivity. 


\section{Conclusions}

Biofield energy treatment on the sponge and bitter gourd was reported with improved growth characteristics such as healthy leaves, fruits, and control from pest attack as compared to their respective control. Biofield treated sponge plants were strong, thin leaves, and uniform color, which suggested higher immunity of plant as compared with the control. Further, the fruits of sponge gourd showed antigravity property at an early stage, along with strong stem as compared with the control plants. However, biofield treated bitter gourd showed the uniform color of leaves, strong stem, with disease free fruits. It is assumed that biofield treatment might affect the polarization of seeds, and resulted in altered dipole interaction between water and seed during germination. The percentage of true polymorphism observed between control and treated samples of sponge and bottle gourd seed sample was an average value of $7.8 \%$ and $66 \%$, respectively. Overall, study results suggested that $\mathrm{Mr}$. Trivedi's biofield energy treatment has the capability to alter the genetic character of plants, which might be useful in terms of overall crop productivity.

\section{Acknowledgements}

Authors thanks to Bangalore Genei Private Limited, for conducting DNA fingerprinting using RAPD analysis. Authors are grateful to Trivedi science, Trivedi testimonials and Trivedi master wellness for their support throughout the work.

\section{References}

[1] Henriques F, Guine R, Barroca MJ (2012) Chemical properties of pumpkin dried by different methods Croat. J Food Technol Biotechnol Nutr 7, 98-105.

[2] Oboh IO, Aluyor EO (2009) Luffa cylindrica - an emerging cash crop. Afr J Agric Res 4: 684-688.

[3] Leung L, Birtwhistle R, Kotecha J, Hannah S, Cuthbertson S (2009) Anti-diabetic and hypoglycaemic effects of Momordica charantia (bitter melon): A mini review. Br J Nutr 102: 17031708 .

[4] Miniraj N, Prasanna KP, Peter KV (1993) Bitter gourd Momordica spp. In: Kalloo G, Bergh BO (edns) Genetic improvement of vegetable plants. Pergamon Press, Oxford.

[5] Singh AK (1990) Cytogenetics and evolution in the Cucurbitaceae. In: Bates DM, Robinson RW Jeffrey C (eds) Biology and utilization of Cucurbitaceae. Cornell Univ Press, Ithaca, New York.

[6] Welihinda J, Karunanayake EH, Sheriff MHH, Jayasinghe KSA (1986) Effect of Momordica charantia on the glucose tolerance in maturity onset diabetes. J Ethnopharmacol 17: 277-282.

[7] Raman A, Lau C (1996) Anti-diabetic properties and phytochemistry of Momordica charantia L. (Cucurbitaceae). Phytomedicine 2: 349-362.
[8] Dey SS, Singh AK, Chandel D, Behera TK (2006) Genetic diversity of bitter gourd (Momordica charantia L.) genotypes revealed by RAPD markers and agronomic traits. Sci Hort 109: 21-28.

[9] Thormann CE, Ferreira ME, Camargo LEA, Tivang JG, Osborn TC (1994) Comparison of RFLP and RAPD markers to estimating genetic relationships within and among Cruciferous species. Theor Appl Genet 88: 973-980.

[10] Rafalski JA, Tingey SV (1993) Genetic diagnosis in plant breeding: RAPDs, microsatellites and machines. Trends Genet 9: $275-280$.

[11] Tuteja N, Gill SS, Tuteja R (2012) Improving crop productivity in sustainable agriculture. Wiley $\mathrm{VCH}$.

[12] Maffei ME (2014) Magnetic field effects on plant growth, development, and evolution. Front Plant Sci 5: 445.

[13] Mahajan TS, Pandey OP (2015) Effect of electric and magnetic treatments on germination of bitter gourd (Momordica charantia) seed. Int J Agric Biol 17: 351-356.

[14] Alexander MP, Doijode SD (1995) Electromagnetic field, a novel tool to increase germination and seedling vigour of conserved onion (Allium cepa L.) and rice (Oryza sativa L.) seeds with low viability. Plant Genet Resour Newslett 104: 1-5.

[15] NIH, National Center for Complementary and Alternative Medicine. CAM Basics. Publication 347. [October 2, 2008]. Available at: http://nccam.nih.gov/health/whatiscam/

[16] Lenssen AW (2013) Biofield and fungicide seed treatment influences on soybean productivity, seed quality and weed community. Agricultural Journal 8: 138-143.

[17] Nayak G, Altekar N (2015) Effect of biofield treatment on plant growth and adaptation. J Environ Health Sci 1: 1-9.

[18] Trivedi MK, Patil S, Shettigar H, Bairwa K, Jana S (2015) Phenotypic and biotypic characterization of Klebsiella oxytoca: An impact of biofield treatment. J Microb Biochem Technol 7: 203-206.

[19] Trivedi MK, Patil S, Nayak G, Jana S, Latiyal O (2015) Influence of biofield treatment on physical, structural and spectral properties of boron nitride. J Material Sci Eng 4: 181.

[20] Shinde VD, Trivedi MK, Patil S (2015) Impact of biofield treatment on yield, quality and control of nematode in carrots. J Horticulture 2: 150 .

[21] Green MR, Sambrook J (2012) Molecular cloning: A laboratory manual. (3rdedn), Cold Spring Harbor, Cold Spring Harbor Laboratory Press, NY.

[22] Borges A, Rosa MS, Recchia GH, QueirozSilva JRD, Bressan EDA, et al. (2009) CTAB methods for DNA extraction of sweet potato for microsatellite analysis. Sci Agric (Piracicaba Braz) 66: 529-534.

[23] Welsh J, McClelland M (1990) Fingerprinting genomes using PCR with arbitrary primers. Nucleic Acids Res 18: 7213-7218.

[24] Zalapa JE, Staub JE, McCreight JD (2006) Generation means analysis of plant architectural traits and fruit yield in melon. Plant Breeding 125: 482-487.

[25] Sun Z, Lower RL, Staub JE (2006) Analysis of generation means and components of variance for parthenocarpy in cucumber (Cucumis sativus L.) Plant Breeding 125: 277-280. 
[26] Ye ZH, Lu ZZ, Zhu J (2003) Genetic analysis for developmental behavior of some seed quality traits in Upland cotton (Gossypum hirsutum L.) Euphytica 129: 183-191.

[27] Florez M, Carbonell MV, Martinez E (2007) Exposure of maize seeds to stationary magnetic fields: Effects on germination and early growth. Environ Exp Bot 59: 68-75.

[28] Xu C, Wei S, Lu Y, Zhang Y, Chen C, et al. (2013) Removal of the local geomagnetic field affects reproductive growth in Arabidopsis. Bioelectromagnetics 34: 437-442.

[29] Anand A, Nagarajan S, Verma AP, Joshi DK, Pathak PC, et al. (2012) Pre-treatment of seeds with static magnetic field ameliorates soil water stress in seedlings of maize (Zea mays L.). Indian J Biochem Biophys 49: 63-70.

[30] Raj M, Prasanna NKP, Peter KB (1993) Bitter gourd Momordica ssp. In: Berg BO, Kalo G (eds) Genetic improvement of vegetable crops. Pergmon Press, Oxford.
[31] Archak S, Karihaloo JL, Jain A (2002) RAPD markers reveal narrowing genetic base of Indian tomato cultivars. Curr Sci 82: 1139-1143.

[32] Sances F, Flora E, Patil S, Spence A, Shinde V (2013) Impact of biofield treatment on ginseng and organic blueberry yield. Agrivita J Agric Sci 35: 22-29.

[33] Shinde V, Sances F, Patil S, Spence A (2012) Impact of biofield treatment on growth and yield of lettuce and tomato. Aust J Basic Appl Sci 6: 100-105.

[34] Dalamu, Behera TK, Gaikwad A, Saxena S, Bharadwaj C, et al. (2012) Morphological and molecular analyses define the genetic diversity of Asian bitter gourd (Momordica charantia L.). AJCS 6: 261-267. 